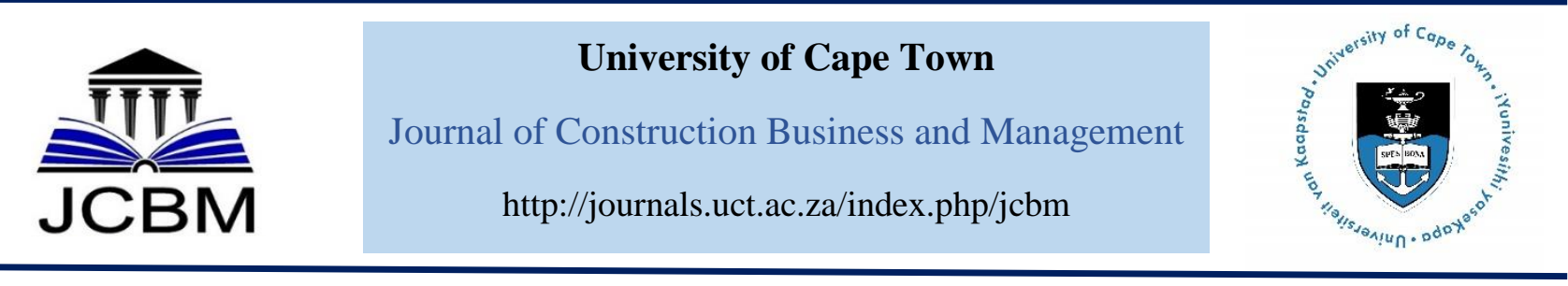

\title{
Building Information Modelling and Collaboration in the Nigerian Construction Industry
}

\author{
I. O. Onungwa ${ }^{1}$, N. Uduma-Olugu ${ }^{2}$ \\ Department of Architecture., University of Lagos, Nigeria ${ }^{1,2}$
}

Received 30 October 2016; received in revised form 6 December 2016, 31 January 2017and 1 March 2017; accepted 15 March 2017

\begin{abstract}
Building Information Modelling (BIM) is a concept that is transforming the way construction is done internationally. Nigeria is lagging regarding the adopting BIM as a collaborative tool amongst professionals in Architecture, Engineering, and Construction (AEC) industry. The thesis of this paper is to investigate how BIM has been adopted in Nigeria and determine to what extent it has helped in improving collaboration among stakeholders in Nigerian construction industry. The method adopted is that of the structured questionnaire. The questionnaires which were organized to capture the central thesis of this study were distributed among 30 AEC firms selected through the simple random sampling method. The responses derived from the responses of respondents were carefully analysed and showed that BIM has significant impacts in areas such as client satisfaction, time for completion, quality and presentation of different concepts in schematic design. The responses also showed a high impact on conflict resolution, supervision, construction programming and quality of completed jobs during the post-contract stage. Major challenges militating against the adoption of BIM were identified to include inadequate infrastructure, lack of skilled workers and insufficient awareness of BIM technology. For Nigeria to compete internationally in the construction industry, BIM should be adopted; hence, there is a need for a more sustained study in this area. The study identified several recommendations which, when applied, can engender a more improved management in the construction industry in Nigeria. Some of the recommendations include: first: developing a curriculum that will incorporate the study of BIM in courses relating to construction. Second: establishment of learning centres that deal with studies in new trends in technology should be developed for private practitioners. Third: relevant professional bodies should create awareness or publicity about the effectiveness of BIM and; fourth, incentives should be made available to AEC firms so as to encourage the use of BIM and collaboration among stakeholders.
\end{abstract}

Keywords: Adoption; Building information modelling; Collaboration; Construction lifecycle.

\section{Introduction}

BIM is a product of the general improvement in technology that is created to encourage teamwork and collaboration during the design and construction period. Lucas (2015) averred that BIM is a process that acutely increases the ability to collaborate and exchange information throughout a project's lifecycle from its conception through design, construction, facility management, and decommissioning. BIM technologies have been developed primarily as a solution to information and co-ordination problems (Baddeley and Chang, 2015). According to Holness (2008), BIM is the assembly of a single database of fully integrated and interoperable information that can be used seamlessly and sequentially by all members of the design and construction team and ultimately, by owners/operators throughout a facility's life cycle.

Efforts at adopting BIM in Nigeria's private and public sector and amongst different building professionals (Architects, Quantity Surveyors, Civil Engineers, etc.) have been very slow. Architects have adopted BIM, but they have done so mainly for enhancing the visual quality of their presentation (Alufohai, 2012). Other professionals continue to produce their drawings with 2D Auto Cad. As a result, collaboration on BIM-based projects is not

\footnotetext{
${ }^{1}$ Corresponding Author. Tel: +234 8036767760

Email address: digitdesign@yahoo.com

${ }^{2}$ Email address: nnezi.udumaolugu@gmail.com
} 
effective. BIM allows for collaboration in design at the early stage of a project. Usually, this enables consultants to take their decisions at a project's early stage and reduce changes that may occur at a later stage in the design process.

BIM is fast dictating the pace of professionals in the construction industry and changing the process of design and construction of buildings. Hassan and Yolles, (2009) stated that the 3D modelling process extends to scheduling and sequencing (4D), cost estimating (5D), sustainable design also termed Green Design (6D) and facility management (7D). BIM is a new approach to design, depending on the extent of collaboration between Architects, clients, Engineers, building services, manufacturers, contractors and other consultants. It is a team approach in which inputs of all professionals in the design are captured in the same model. "It is a unique opportunity for the building industry to have a shared model that incorporates various building components, including the building's geometry, its spatial relationships, and indeed, its material properties and quantities" (Hassan and Yolles, (2009). The most common programs for BIM are Autodesk Revit, Microstation, ArchiCAD, CBIM, and Ruska.

Baddeley and Chang (2015) noted that collaboration is inherently about harnessing social influences - the tendency humans have to co-operate with others. Therefore, developing collaborative interaction across professions has become a key issue for both academics and practitioners in recent times (Lu, Zhang, and Rowlinson, 2013). Some studies have expressed poor productivity and fragmentation in construction industry (see Lu et al., 2013). For Nigeria to compete globally in construction, the full potentials and opportunities provided by BIM as a collaboration tool have to be utilized. Using BIM as a mechanism during a project's lifecycle will greatly bolster efficiency in the construction of buildings and reduce the problems that are likely to occur during construction.

Among professional bodies interested in construction in Nigeria, there is limited use of BIM due mainly to their inability to keep pace with the modern advancement in technology, their level of awareness about BIM is low. It is in this light that the major factors that impede the adoption of BIM are identified and discussed here. In highlighting the factors impeding the utilization of BIM, it is the hope of this study that the relationship between stakeholders in the construction industry will be strengthened and values that can be derived from this model will be identified. Few studies have been done focusing on the adoption of BIM in the Nigerian construction market. In the same vein, other studies have emphasized the benefits that can be derived from BIM in the industry. Equally, elsewhere in the world, the capacity of BIM to foster collaboration in technology has been explored. Abubakir, Ibrahim, and Kado (2014) explored contractor's perception of factors affecting BIM in the Nigerian construction industry. Zhang and Rowlinson (2013) focused on BIM collaboration: A conceptual model and its characteristics. However, studies that centralize BIM as a powerful tool that ensures collaboration during the life cycle of the project is yet to be conducted in Nigeria. It is assumed that the use of BIM will improve the design process and enhance collaboration amongst professionals during schematic design and post-contract stage of design. Important as well is that studies have not been done to determine if indeed BIM promotes collaboration. Also, there has been no effort at discussing why there has not been any significant collaboration among professionals and disciplines within the construction industry in Lagos, Nigeria. If there has not been any collaboration among professionals in the construction industry in ensuring innovations in their field, then a study that will show that interoperation is needed becomes necessary.

Collaboration and improvement in communication and efficiency during construction is one of the major advantages of BIM. This also accounts for one of the problems militating against innovations in the Nigerian construction industry. Therefore, the present paper investigates the factors impeding the utilization of BIM in Nigeria. In doing this, it advocates for an interdisciplinary collaboration among professionals in the construction industry with a view to identifying measures that will make for its improvement.

\section{Literature review}

The present paper aims at exploring how the Building Information Modelling (BIM) can provide a framework for collaboration among key stakeholders in the construction industry. Although several kinds of literature on the Building Information Modelling is available, few have been done in relation to the Nigerian context. Therefore, the reviews that will be done here will highlight the studies that have been undertaken so far and show its relevance to the Nigerian situation. To do this, the review will give a historical survey of the development of the BIM to demonstrate the innovations that have been introduced to it at different stages. Since the model is useful in enabling technological and interdisciplinary collaboration among professionals in the construction industry, its relevance will also be highlighted. The review will also highlight the challenges that exist in the adoption of BIM. Equally relevant is the way in which the review will show how BIM occupies a central mechanism for architectural design management and, indeed, an effective collaborative tool.

\subsection{Historical account of BIM}

In the 1950s, The United States Military pioneered the development of the first graphic system called SAGE (Semi Auto Ground Environment.) The system was developed in partnership with the Lincoln Laboratory of Massachusetts Institute of Technology (MIT). In the 1960s, Ivan Sutherland, a researcher at MIT developed the sketchpad. "From the roots of the SAGE graphical interface and Ivan Sutherland's Sketchpad program in 1963, solid modelling programs began to appear building on developments in the computational representation of geometry." (http://www.archdaily.com/302490/a-briefhistory-of-bim).

One of the first projects to successfully create a building database was the Building Description System 
(BDS) which was the first software to describe individual library elements which can be retrieved and added to a model. This project was created by Charles Eastman. In 1977, Eastman created GLIDE (Graphical Language for Interactive Design) which has most of the characteristics of current BIM." In the 1970s and 1980s, several developments continued around the world. "The BDS approach tended to be described as "Building Product Models" in the USA, and "Product Information Models" in Europe. These phrases then merged to become "Building Information Model".

\subsection{The relevance of BIM in the construction industry}

There have been many discussions on BIM; however, there has arguably been no attempt to relate the discussions of the model to the Nigerian context. BIM has been in use for many years in Nigeria. However, its effectiveness and indeed its potentials have hardly been maximized. The benefits involved in engaging in the use of BIM as a collaborative tool include: leveraging on the value of good, reliable information, enabling better coordination, synchronization, and sequencing of projects, by allowing all project participants to access and interrogate project information. At a higher level, BIM enables better clash detection (Baddeley and Chang, 2015). Collaboration is often difficult to achieve because the degree of adoption of BIM among the different stakeholders in the construction industry is not the same.

According to Eastman et al. (2011), BIM can potentially increase the efficiency, quality, and productivity of construction projects by reducing the number of mistakes and incompatibilities, providing more accurate and up-to-date information, and by giving a more illustrative and accessible exposition of a building. There are many benefits of BIM and key among others is the ability to reuse information stored in a database (Egbu and Sidawi, 2012). Automation through BIM also improves time and cost management. It streamlines the design process across the company and facilitates automation of emails via knowledge database.

Other benefits include an ability to visualize what is to be built in a simulated environment, higher reliability of expected field conditions, and allowing for an opportunity to do more prefabrication of materials off-site (Rajedran and Clarke, 2011). According to Gordon and Holness (2008), the building design development can continue with the provision of bills of material and generation of shop drawings automatically for everything ranging from structural steel to sheet metal duct fabrication, to fire protection and piping fabrication, to electrical cabling and bus duct layouts.

\subsection{Challenges and barriers to BIM adoption in Nigeria}

Oladapo (2006) studied the adoption of ICT in the Nigerian construction industry and concluded that the most important obstacle is the poor state of electricity and other infrastructures. Lack of constant electricity and lack of internet connectivity affect the output of work in offices (Abubakir et al., 2014). Constant use of generators increases the cost of running the offices. Moreover, Internet connection is necessary for adequate use of the
BIM. Internet should be available to get drawings from a vendor site. BIM systems create big files, implying that the management and transfer of these records will be difficult to do in Nigeria, given the slow internet speed and electricity supply problems. This is in addition to the fact that the use of internet facilities in Nigeria certainly increases the cost of production.

Key of the challenges posed by the adoption of BIM in Nigeria is the interoperability risks between different programs used. (Azhar et al., 2012). This affects the collaboration of construction working drawings and limits the use of BIM, especially during the post-contract stage. A survey by AEC bytes showed that despite each discipline working in $3 \mathrm{D}$ environment, collaboration is still primarily based on the exchange of 2D drawings (Khemlani, 2007).

The ownership of BIM data has not yet been determined. It is not yet clear if the BIM belongs to the client who paid for it to be done or the Architect who developed the model. This can create conflict if the client decides to get inputs from other consultants by himself. In most instances, the Architect has to bear the cost of changes in the model during construction, as the client is usually not willing to pay for extra expenses. "BIM entails a high setup cost in both software investment and training, potentially hindering the initial rate of conversion. The nebulous benefit of BIM perceived by individual users also intensifies the resistance to this new technology. In the short run, a proper incentive system can help lift most of the barriers" (Baddeley and Chang, 2015). Most BIMs in use do not have object libraries that are utilized in the Nigerian Market. Even so, the standards for drawing presentation have not been developed.

The Integrated concept of BIM increases risk and liabilities to different parties involved (Azhar et al., 2011). This creates problems when vendors and other consultants make an input to the BIM. There are also various barriers to the adoption of BIM. One of them is the lack of skilled personnel (Abubakir et al., 2014). There are not enough trained personnel in the industry. Most architects train themselves or learn on the job. Therefore, they are usually not aware of all innovations in technologies in the software. Additionally, the reluctance of other stakeholders in using BIM makes it difficult for architects who must transform their drawings to AutoCAD to allow other consultants do their jobs.

Another barrier to the adoption of BIM is the "fear of change" (Hassan and Yolles, 2009). Most people are comfortable with the software they use and, as a result, find it difficult to change or switch to another one, even though it may be more advanced. Using BIM means a shift in mindset from developing drawings with lines to developing drawings in three dimensions putting in walls, windows, doors and other building components (Hassan and Yolles, 2009).

According to Farley (2011), "lack of BIM object libraries" affects the production of drawings because some products are not available in the software. Many professionals in the construction industry are still not aware of the technology. If BIM innovations can be designed to enable inter-disciplinary learning and promote collaboration throughout a project supply chain, 
then the efficiency savings are likely to be large (Baddeley and Chang, 2015).

Most of the countries that have successfully adopted BIM have government participation. Alufohai (2012) also stressed the necessity for government involvement; Government has helped to achieve progress in most countries. The General Services Administration (GSA) in the U.S.A made the use of BIM a requirement on all major projects receiving significant public funding in 2007. In Finland, the Senate Properties, a government owned organization implemented BIM Requirements in October 2007. Such a role has been played by governments in Northern Europe. In Singapore, the CORENET e-PLAN Check system (Construction Real Estate Network), launched by Singapore's Ministry of National Development) provides automated compliance checking against building codes for schemes designed using BIM. Lack of Government encouragement or incentive is one of the factors affecting adoption of BIM.

\subsection{The relevance of $B I M$ as an architectural design management}

It is believed that the implementation of BIM may lead to significant improvement in architectural design team performance. According to Emmitt (2010), the management of architectural design is essential for delivering design intent and maximizing value to a wide range of stakeholders. Birx (2008) posited that the Geometrical CAD did not significantly affect the way architects work, but only computerized the drawing practice which was in the past done with boards. His studies also showed that with the increase in the use of BIM in the construction industry, there would be cultural changes in several design aspects, constructive processes, services offered, and organizational structure of the companies.

Ballard and Koskela (1998) noted that one major reason for the poor level of design management is the lack of solid conceptual foundation. The use of BIM enables input of all professionals in the design process at the conceptual stage. The principal partner and other Architects in the Architectural practice can make inputs at the conceptual stage. The client can also easily visualize the project.

The use of the BIM allows design improvement with a reduction of errors, as it anticipates the design definitions. In this way, it avoids problems in future stages, where the modifications usually generate huge consequences. According to Souza et al., (2009), the ease of visualization through countless cross-sections, views, and perspectives also contributed to the generation of more intelligent design solutions. The automatic generation of views and cross-sections leads to the possible reduction of the work. Offices can meet delivery deadlines with the reduction of the workload spent on each project.

\subsection{Use of BIM as a collaboration tool}

Collaboration is essential for success in the management of any construction project. However, the construction industry has problems of fragmentation and non- collaboration amongst stakeholders. Collaboration in BIM addresses collaboration amongst the different disciplines involved in the construction project during the various stages of the project's life cycle. The potential of any collaboration depends on cognitive perception, trust, and planning ( $\mathrm{Lu}$ et al., 2013). A cross-profession collaboration theory claims three determinants of successful collaboration: Collaborative team characteristics, collaboration environment characteristics, and collaborative processes (Lu et al., 2013).

The collaborative team involves relevant knowledge, skills, and attitude to work. Collaborative environment denotes institutional support, while collaborative processes are effective communication, clarity and conflict resolution processes (Lu et al., 2013). BIM is a collaborative approach to construction concerned with integrating the various disciplines to build a structure in a virtual and visual environment (Lu et al., 2013).

Given the studies reviewed, there must be a collaborative team, institutional support and efficient communication for BIM to work effectively. On its part, effective communication allows stakeholders from different disciplines to exchange detailed and accurate information. BIM focuses on series of activities, high levels of data input and highly skilled personnel. For BIM to work effectively, the environment for collaboration has to be in place. There must be institutional support from Architects and Engineers. Without this support, the fragmentation which currently exists in the industry will continue, despite the advent of new technology. In Europe and America, Architects and Engineers have been able to integrate their works in the same BIM model.

In Nigeria, "due to non-integration between the architect, M\&E, structural engineer, and the general contractor, it is observed that there are clashes between the M\&E design and that of the architect such as a sewage pipe hitting or passing through a beam which is only found out on site during the construction exercise" (Dim et al., 2015).

\subsection{Measures of collaboration}

Collaboration in BIM is a requirement. Different parties share their knowledge and expertise in a single model. BIM supports integrated project delivery by providing platform and tools for collaborative design and project management (Hamid and Pardis, 2014). For collaboration to be monitored, there must be measures for collaboration. In construction management, several key performance indicators (KPI's) have been identified. These include cost, time, and quality, team performance, communication, stake-holder and human resource management. Brewer and Mendelson (2013) identified traits in an effective team that can result in collaboration. These include creativity, productivity, co-location, commitment, multidisciplinary work, decision authority, productive environment, training, accountability, consensus leader selection, aligned people and organization, aligned process and practices. Hamid and Pardis (2014) developed a collaboration assessment tool to monitor collaboration. Factors to be considered in their assessment tool include personal and team characteristics, training, human-human interactions, human - computer 
interactions, communication channels and physical location of team members.

To measure collaboration in BIM, its effect on productivity in the construction industry must be considered. "Coates et al. (2010), developed some KPIs from a case study, focusing on the business impact of BIM, including speed of development, improvement in skills and knowledge, reduction of costs, travel, printing, document shipping, and better architecture and deliverables."

To determine challenges to BIM adoption and lack of collaboration amongst professionals and disciplines within the construction industry, measures of collaboration in BIM need to be developed. Measurement of collaboration in BIM will include: personal and team characteristics, human interactions within the BIM model, channels of communication for team members as well as physical locations of team members. We will also examine the impact of BIM in construction life-cycle in Nigeria. These include the impact on the speed of development, quality, time of completion, reduction in changes and reduction in cost.

\section{Research Methodology}

\subsection{Aim and objectives}

The central purpose of this study is to explore the use of Building Information Modelling in Nigeria and evaluate the factors that affect its adoption within the context of AEC (Architecture Engineering Construction) projects in Lagos, Nigeria. Other subsidiary objectives are to: assess how BIM is adopted amongst stakeholders in the Nigerian construction market; identify and discuss barriers to BIM adoption in Lagos, Nigeria, during schematic and postcontract stages of design; and determine and analyse the factors which enhance the use of BIM as a tool for collaboration among stakeholders in the Nigerian construction industry. The study is limited to construction projects. Architects and other consultants within the AEC industry are the main focus of study.

\subsection{Methodology}

The method used in the study were got through a literature review of research subject matter, the literature review of various methodologies that have been used in practice and review of existing theories in practice. Abubakar et al. (2015) used structural questionnaires as a tool for collecting data in their research on factors affecting BIM in Nigerian construction industry. Dim et al. (2015) studied case studies of different projects for their research on managing change process with BIM implementation by public and private investors in Nigeria. Oladapo (2006) used questionnaires to survey participants in AEC industry.

For this study, structured questionnaires were given to 30 professionals in the construction industry. The sample were chosen from professionals already using BIM in their practice. Lagos and environs were selected for the case study because of the unique position of Lagos in Nigerian construction industry. "Lagos has the highest estimated population of 18 million representing $12 \%$ out of a national estimate of 150 million with annual growth rate of between $6 \%$ and $8 \%$ compared to $4-5 \%$ country growth rate and global $2 \%$ growth rate. It is the second most populous city in Africa after Cairo in Egypt and estimated to be the fastest-growing city in Africa and the seventh fastest growing in the world (Oshodi., 2010).

Questionnaires were developed using theories identified in the field; Technology acceptance model and Task-technology fit. Technology acceptance model was used to develop questions on acceptance of BIM as a tool for design development; Questions included perceived ease of use, the usefulness of BIM, reasons for adoption or lack of adoption, and level of acceptance for architectural design.

Task Technology Fit model was used to develop questions on the use of BIM as a functional tool in various aspects of the construction industry: quality, time management, presentation of design concepts, conflict resolution, cost estimation, change management, safety, and construction programming.

Questions included the impact of BIM on schematic design stage, impact on post contract stage, factors preventing the adoption of BIM and solution to challenges. Answers from respondents were collected and analysed. Data was collected using Likert scale to rank level of impact of BIM during schematic design and post contract stage using different variables.

Data was analysed using SPSS version 22. Data from questionnaires were imported into the software and analysed. The results from the variables were tabulated and the mean value determined. The mean values were used to determine variables with highest impact on post contract stage of design and schematic stage od design. This method was used because data collected were easily analysed and deductions were extrapolated. It is also accurate and easy to understand.

The test of the reliability of the responses to the study of the impact of BIM on collaboration in schematic design and post contract design stage was determined using standardised Cronbach's Alpha. Analysis of variance (ANOVA) was used to test if there is significant variation in how the respondents rated the items in each section of the instrument.

\section{Finding and Discussion}

Data from questionnaires were analysed and findings from the study are discussed in this section.

Table 1 shows the reliability analysis of questionnaire on impact of BIM on collaboration in schematic design and post contract design stage 
Table 1: Reliability Test Results of Instrument

\begin{tabular}{|c|c|c|c|c|c|c|c|c|}
\hline \multirow{2}{*}{$\begin{array}{c}\text { Instrument } \\
\text { Source }\end{array}$} & \multicolumn{5}{|c|}{ Scale Statistics } & \multirow{2}{*}{$\begin{array}{c}\begin{array}{c}\text { Reliability } \\
\text { Statistics }\end{array} \\
\begin{array}{c}\text { Cronbach's } \\
\text { Alpha }\end{array}\end{array}$} & \multicolumn{2}{|c|}{$\begin{array}{c}\text { Validity Statistics } \\
\text { (ANOVA) }\end{array}$} \\
\hline & $\begin{array}{l}\text { No. of } \\
\text { Items }\end{array}$ & $\begin{array}{l}\text { Number of } \\
\text { Samples }\end{array}$ & Mean & SD & $\mathrm{CV}$ & & F-value & P-value \\
\hline $\begin{array}{c}\text { Impact of BIM on Schematic } \\
\text { design stage }\end{array}$ & 6 & 16 & 26.810 & 2.040 & 0.080 & 0.737 & 140.904 & 0.000 \\
\hline $\begin{array}{l}\text { Impact of BIM on Post } \\
\text { Contract design stage }\end{array}$ & 9 & 16 & 38.310 & 3.610 & 0.090 & 0.767 & 22.735 & 0.000 \\
\hline Factors Preventing Adoption & 9 & 16 & 32.190 & 4.722 & 0.150 & 0.760 & 32.626 & 0.000 \\
\hline
\end{tabular}

The test of the reliability of the responses on the study of the impact of BIM on collaboration in schematic design and post contract design stage, using standardized Cronbach's Alpha is obtained for each section as 0.737 , 0.767 and 0.760 . These results suggest that the instrument of evaluation is highly reliable judging from the fact that $0.737,0.767$ and 0.76 are more than 0.70 threshold value, respectively. A reliable coefficient of 0.7 or higher is considered acceptable for internal consistency of the items in the instruments (questionnaires) used for data collection.

These results are supported by the coefficient of variation $(\mathrm{CV})$ values; $0.08,0.09$ and 0.15 , which are

Table 2: Analysis of Socio-Economic Variables respectively less than 0.50 threshold value, indicating homogeneity on how the respondents rated the items. Hence, there is an internal consistency of the answers from the respondents, and therefore the data do not violate the assumption of reliability. The result of the analysis revealed that the test is significant at F-value $=140.904$, 22.735 and $32.626, \mathrm{P}<0.05$, respectively. The results suggested no significance variation on the rating of the items by respondents in the instruments. Hence, the reliability of the tools is significant, which validates the adequacy of the instruments.

\begin{tabular}{|c|c|c|c|c|c|}
\hline Variable & Characteristics & Freq. & $\%$ & Mean & Total \\
\hline \multirow{3}{*}{ Address } & Within Lagos & 12 & 75.0 & & \\
\hline & South West & 3 & 18.8 & & \\
\hline & South South & 1 & 6.3 & & 16 \\
\hline \multirow{4}{*}{ Years in Business } & $1-5$ years & 5 & 31.3 & & \\
\hline & $6-10$ years & 2 & 12.5 & & \\
\hline & 11-15years & 6 & 37.5 & & \\
\hline & Over 21 years & 3 & 18.8 & 10.8 & 16 \\
\hline \multirow{4}{*}{ Total No of Employees } & $1-5$ staff & 8 & 50.0 & & \\
\hline & $6-10$ staff & 6 & 37.5 & & \\
\hline & $11-15$ staff & 1 & 6.3 & & \\
\hline & Over 21 staff & 1 & 6.3 & 7 & 16 \\
\hline \multirow{3}{*}{ What kind of projects do you do? } & Mostly residential & 1 & 6.3 & & \\
\hline & Mostly commercial & 1 & 6.3 & & \\
\hline & All Types & 14 & 87.5 & & 16 \\
\hline $\begin{array}{l}\text { Indicate if any Building information modelling software is used } \\
\text { in your practice? }\end{array}$ & Yes & 16 & 100.0 & & 16 \\
\hline \multirow{2}{*}{ If yes, which software is used? } & Autodesk Revit & 13 & 81.3 & & \\
\hline & ArchiCAD & 3 & 18.7 & & 16 \\
\hline \multirow{2}{*}{$\begin{array}{l}\text { Indicate whether an applicant using BIM would be considered } \\
\text { for employment before one that does not use it? }\end{array}$} & No & 2 & 12.5 & & \\
\hline & Yes & 14 & 87.5 & & 16 \\
\hline
\end{tabular}

Source: Field Survey 2015 
A bulk of the respondents (75\%), were from firms within Lagos, $18.8 \%$ were from other southwestern states, while $6.3 \%$ were from the South region of Nigeria. The highest group of respondents were businesses that had been in operation for $11-15$ years $(37.5 \%)$, followed by those between $1-5$ years $(31.3 \%)$. $18.8 \%$ of the respondents have been in business for over 21 years.

The least number of respondents were those whose business were $6-10$ years old $(12.5 \%)$. The respondents cut across the demographics reflecting the views of both those who have been long in practice and those who are relatively new to practice. $81.3 \%$ of the professionals interviewed use Autodesk Revit in their office while $18.7 \%$ use ArchiCAD. The professionals who are not using BIM stated that they would consider staff using BIM for employment before those not using it. This means that they deem BIM to be an important skill.

Question 1: How has the use of BIM solutions improved drawings during the schematic design stage? This evaluates reasons for adoption of BIM amongst stakeholders in the AEC industry and its effect on collaboration amongst stakeholders.

Table 3: Analysis of Impact of BIM on Schematic Design Stage

\begin{tabular}{lccccccccc}
\hline \multicolumn{1}{c}{ Variables } & \multicolumn{3}{c}{ Response } & \multicolumn{5}{c}{ Descriptive } \\
\cline { 2 - 10 } & $\mathbf{1}$ & $\mathbf{2}$ & $\mathbf{3}$ & $\mathbf{4}$ & $\mathbf{5}$ & Mean & Rank & Relative Index & Extent \\
\hline Client satisfaction & - & - & - & 5 & 11 & 4.69 & 1 & 1.05 & High \\
Quality of drawings produced & - & - & - & 5 & 11 & 4.69 & 1 & 1.05 & High \\
Time of completion of presentation drawings & - & - & 1 & 6 & 9 & 4.50 & 2 & 1.01 & Medium \\
Presentation of different concepts of design & - & 1 & 1 & 3 & 11 & 4.50 & 2 & 1.01 & Medium \\
Collaboration with other staff in the office & - & - & 2 & 7 & 7 & 4.31 & 3 & 0.96 & Low \\
Collaboration with other consultants & - & 1 & 3 & 5 & 7 & 4.13 & 4 & 0.92 & Low \\
Pooled & & & & & & 4.47 & & & 1.00 \\
\hline
\end{tabular}

Source: Field Survey 2015: No effect (1), Worse (2), Negligible (3), Much (4), Very much (5).

From the results, client satisfaction, quality of drawings produced ranked highest with most of the respondents saying BIM affected it very much. The mean value was 4.69. Time for completion of drawings and presentation of different design concepts were next with a mean value of 4.50. Results also show that the effect of BIM on collaboration is low both with staff in the same office and with consultants from other offices; thereby confirming the need to encourage the more collaborative use of BIM (Table 3).

Question 2: How has the use of BIM solutions improved your drawings during post contract design stage? This evaluates the importance of BIM to stakeholders in the AEC industry using key performance indexes.

Table 4: Analysis of Impact of BIM on Post contract design Stage

\begin{tabular}{lccccccccc}
\hline \multicolumn{1}{c}{ Variables } & \multicolumn{4}{c}{ Response } & \multicolumn{5}{c}{ Descriptive } \\
\cline { 2 - 10 } & $\mathbf{1}$ & $\mathbf{2}$ & $\mathbf{3}$ & $\mathbf{4}$ & $\mathbf{5}$ & Mean & Rank & Relative Index & Extent \\
\hline Conflict resolution in drawings & - & - & 1 & 4 & 11 & 4.63 & 1 & 1.09 & High \\
Construction programming & - & - & 2 & 7 & 7 & 4.31 & 2 & 1.01 & High \\
Supervision of Jobs & - & - & 1 & 9 & 6 & 4.31 & 2 & 1.01 & High \\
Quality of completed jobs & - & - & 2 & 7 & 7 & 4.31 & 2 & 1.01 & High \\
Energy efficiency & - & - & 2 & 7 & 7 & 4.31 & 2 & 1.01 & High \\
Time of completion & - & - & 2 & 8 & 6 & 4.25 & 3 & 1.00 & Medium \\
Collaboration with other consultants & - & 1 & 3 & 5 & 7 & 4.13 & 4 & 0.97 & Low \\
Estimation of costs & 1 & - & 1 & 9 & 5 & 4.06 & 5 & 0.95 & Low \\
Safety & - & - & 4 & 8 & 4 & 4.00 & 6 & 0.94 & Low \\
Pooled & & & & & & 4.26 & & & 1.00 \\
\hline
\end{tabular}

Source: Field Survey 2015: No effect (1), Worse (2), Negligible (3), Much (4), Very much (5)

Conflict resolution in drawings was the main advantage in post contract stage of design in Table 4 with a mean value of 4.63. This reinforces the statement that BIM improves co-ordination and efficiency during the post-contract design stage (Table 4). Construction programming, supervision of jobs, quality of completed jobs and energy efficiency were also rated high by the respondents with mean values of 4.31 , whereas collaboration with other consultants, estimation of costs, and safety was considered as having a low impact on the use of BIM at post contract design stage (Table 4).

Question 3: What premium would you place on these factors as the barriers to adoption of Building information modelling in Lagos, Nigeria? This identifies barriers to adoption of BIM. 
Table 5: Analysis of factors preventing Adoption of BIM

\begin{tabular}{|c|c|c|c|c|c|c|c|c|c|}
\hline \multirow{2}{*}{ Variables } & \multicolumn{5}{|c|}{ Response } & \multicolumn{4}{|c|}{ Descriptive } \\
\hline & 1 & 2 & 3 & 4 & 5 & Mean & Rank & Relative Index & Extent \\
\hline Lack of skilled personnel & - & - & 6 & 8 & 2 & 3.75 & 1 & 1.05 & High \\
\hline Lack of internet connectivity & 2 & - & 2 & 8 & 4 & 3.75 & 1 & 1.05 & High \\
\hline Reluctance of other stake holders to use BIM & - & 2 & 5 & 5 & 4 & 3.69 & 2 & 1.03 & High \\
\hline Lack of BIM Object Libraries & - & 2 & 4 & 7 & 3 & 3.69 & 2 & 1.03 & High \\
\hline Lack of awareness of technology & 1 & 2 & 3 & 5 & 5 & 3.69 & 2 & 1.03 & High \\
\hline $\begin{array}{l}\text { Extra costs involved in hardware, software and } \\
\text { developing office procedures }\end{array}$ & - & 3 & 4 & 6 & 3 & 3.56 & 3 & 0.99 & Low \\
\hline Frequent power failures & 2 & 2 & 2 & 8 & 2 & 3.38 & 4 & 0.94 & Low \\
\hline Lack of contractual documents for BIM & 1 & 3 & 3 & 7 & 2 & 3.38 & 4 & 0.94 & Low \\
\hline Fear of change & - & 4 & 6 & 3 & 3 & 3.31 & 5 & 0.92 & Low \\
\hline Pooled & & & & & & 3.58 & & 1.00 & \\
\hline
\end{tabular}

Source: Field Survey 2015: for no impact (1), for little critical impact (2), for fairly critical impact (3), critical impact (4), for extremely critical impact (5).

The major factors preventing the adoption of BIM were identified as lack of skilled personnel and lack of internet connectivity with mean values of 3.75 (Table 5). The reluctance of other stakeholders, lack of awareness of technology and lack of BIM object libraries were also identified as factors preventing adoption. The cost of hardware/software, frequent power failure, lack of contractual documents and fear of change were rated as having a low impact on the adoption of BIM in Nigeria
(Table 5). This was different from studies by Oladapo which identified power supply as the major barrier to adoption of ICT in Nigeria (Oladapo, 2006).

Question 4: What needs to be done in the Nigerian construction industry to encourage efficient utilization of BIM? This identifies factors that will improve adoption and collaboration of BIM.

Table 6: Analysis of solutions to challenges and barriers to Adoption of BIM

\begin{tabular}{|c|c|c|c|}
\hline Items & Frequency & Percent & $\begin{array}{c}\text { Cumulative } \\
\text { Percent }\end{array}$ \\
\hline No answer & 10 & 62.5 & 62.5 \\
\hline Policy makers should promote the use through the result of research done in the Institute & 1 & 6.3 & 68.8 \\
\hline Schools should provide necessary equipment and enforce learning to all students & 1 & 6.3 & 75.0 \\
\hline Seminars, lectures, demonstrations on the use of BIM & 1 & 6.3 & 81.3 \\
\hline The provision of basic infrastructure that will promote the use of BIM & 1 & 6.3 & 87.5 \\
\hline Training and awareness & 1 & 6.3 & 93.8 \\
\hline Training, adaptation to changes & 1 & 6.3 & 100.0 \\
\hline Total & 16 & 100.0 & \\
\hline
\end{tabular}

The responses from the open-ended questions indicated the respondents' opinions on how the barriers could be overcome. Among them are the need for more research,

\subsection{Conclusion}

Some solutions to challenges and barriers to the adoption of BIM, especially in the collaborative manner have been identified from the study. Lack of skilled personnel was identified as one of the major barriers to adoption of BIM. This emphasizes the need to incorporate BIM education in our universities. Lack of infrastructure and reluctance of stakeholders to use BIM were also identified as barriers from literature review and from study.

The study identified client satisfaction and improvement in quality of drawings as the major advantage in adoption of BIM during schematic stage of design. for training at various levels and the provision of basic infrastructure that will promote the use of BIM.

Data from the studies confirms that the main advantage of BIM during post contract stage is conflict resolution. Collaboration with BIM will increase efficiency and quality of construction so awareness needs to be created within the professional bodies.

\subsection{Recommendation}

It is recommended that BIM training centres be established in universities and schools of higher learning, which will be used for training of AEC professionals in the construction industry. BIM as a course should be introduced in all schools of Architecture Engineering, Quantity Surveying, and other construction disciplines 
Nigerian Institute of Architects, Nigerian Institute of Quantity Surveyors and other regulatory bodies in the construction industry need to get involved with BIM and help in its standardization in Nigeria.

The Federal government of Nigeria and other building and construction agencies should enforce the use of BIM by organizing workshops and seminars to educate owners, Architects, Engineers, Contractors and other stakeholders on the uses and advantages of BIM for public and private

\section{References}

Abdirad, H and Pishdad-Bozorgi, P. 2014. Developing a framework of metrics to assess collaboration in integrated project delivery retrieval. 50th ASC Annual International Conference Proceedings, Associated Schools of Construction. 26-28 March 2014, Virginia Tech, Blacksburg, VA.

Abubakar M., Ibrahim Y., Kado D. and Bala, K. 2014. Contractor's perception of factors affecting building information modelling in the Nigerian construction industry. Computing in Civil Engineering, ASCE 2014, 167-178.

Adesina, A. A, Ayo C.K. and Ekong U.O. 2008. An empirical investigation of the level of user's acceptance of e-banking in Nigeria: based on technology acceptance model. Journal of Internet banking and commerce. 15 (1).

Online http://www.arraydev.com/commerce/JIBC151.htm .(April 2012)

Alufohai, A. 2012. Adoption of building information modelling and Nigeria's quest for project cost management, in FIG Working Week 2012, Knowing to manage the territory, protect the environment, evaluate the cultural heritage,6-10 May 2012, Rome, Italy.

Autodesk. 2016. What is BIM? http://www.autodesk.com/solutions/bim/overview. (May 12,2014)

Azhar, S., Hein, M. and Sketo, B. 2011. Building information management benefits, risks, and challenges. Leadership and Management in Engineering, ASCE 2011, 11(3); 241-252

Azhar, S., Khalfan, M. and Maqsood, T. 2012. Building information modelling (BIM): now and beyond. Australasian Journal of Construction Economics and Building, 4:15-28.

Baddeley, M. and Chang, C. 2015. Collaborative Building information modelling (BIM): insights from behavioural economics and incentive theory. RICS Research publication. Online https://researchgate.net/ publication/281243999 (March 2015).

Ballard, G. and Koskela, L. 1998. On the Agenda of design management research, Proceedings of IGLC '98. Guaruja, Brazil

Birx, G. W. 2008. Getting started with Building Information Modelling. The American Institute of Architects - Best Practices, www, ashrae.org (June 2015)

Brewer, W.and Mendelson, M. I. 2003. Methodology and metrics for assessing team effectiveness. The International Journal of Engineering Education, 19: 777787. construction projects in Nigeria. The government can start by making BIM mandatory for all government projects. There is a need for more research on the use of BIM in construction in Nigeria.

For effective collaboration, institutional support from the private offices is very important. The leaders in private firms have to be committed to this. For this to happen, there must be some remuneration for efforts made in investing on new software and training.

CICRP. 2009. BIM project execution planning guide. The Computer Integrated Construction Research Group, The Pennsylvania State University, PA.

Coates, P., Arayici, Y., Koskela, L., Kagioglou, M., Usher, C., and O'Reilly, K. 2010. The key performance indicators of the BIM implementation process. Paper presented at The International Conference on Computing in Civil and Building Engineering, April 2010, Nottingham, UK.

Davison, R. M., Martinsons, M. G. and Kock, N. 2004. Principles of canonical action research. Information Systems Journal, 14: 65-86.

Deluca, D. 2008. Furthering information systems action research: A post-positivist synthesis of four dialectics. Journal of the Association for Information Systems,

$9(2): 48-72$.

Dim, N. U., Basili, E. and Okoro, B. 2015. Managing change process with BIM implementation by public and private investors in Nigerian Building industry. Donnish Journal of Engineering and manufacturing technology, 2:001-006.

Eastman, C., Teicholz, P., Sacks, R. and Liston, K. 2011. BIM Handbook, a guide to building information modelling for owners, managers, designers, engineer, and contractors. New Jersey: John Wiley and Sons, Inc.

Egbu, C. and Sidawi, B. 2012. Building information modelling (BIM) implementation and remote construction projects; issues, challenges, and critiques. Journal of information technology in construction, 47: 7585.

Emmitt, S. 2010. Design management in architecture, engineering, and construction: Origins and trends. Gestão \& Tecnologia de Projetos, 5(3).

Farley, A. 2011. Assessing the impacts of building information modelling. The building Economist, June 2011:13-19.

Gianina. LALA (FĂDOR).2014 The Emergence and Development of the Technology Acceptance Model (TAM), International Conference Marketing from information to decision, November 2014:7; 149

Gordon, V. and Holness, P. 2008. BIM gaining momentum. ashrae.org, June 2008: 28-30.

Hassan, A. and Yolles, H. 2009. Building information modelling, a primer. Canadian Consulting Engineer, June/July 2009: 42.

Iversen, J. H., Mathiassen, L., and Nielsen, P. A. 2004. Managing risk in software process improvement: An action research approach. MIS Quarterly, (28)3: 395 433.

Khemlani, L. 2007. Top criteria for BIM solutions, a survey conducted by AECbytes. http://www.aecbytes.com/feature/2007/BIMSurveyRepo rt.html. (11 November, 2015) 
Lu, W., Zhang, D. and Rowlinson, S. 2013. BIM collaboration: A conceptual model and its characteristics. 29th Annual ARCOM Conference, 2-4 September 2013. Reading, UK: Association of Researchers in Construction Management. 25-34.

Lucas, J. 2015. Managing the facility with lifecycle information. Journal of Current Issues in Media and Telecommunications.7(1):13-35.

Markauskaite, L., Fitzgerald, R., Herrington, J., and Wallace, R. 2011. eResearch in education: An overview and selected resources 17 April 2011. AARE/ARDEN eResearch task group report prepared for the Australian Association for Research in Education.

Markauskaite, L. and Reimann, P. 2014. Editorial: eResearch for education: Applied, methodological and critical perspectives. British Journal of Educational Technology, 45 (3).

Oladapo, A. A. 2006. The impact of ICT on professional practice in the Nigerian construction industry. Electronic Journal for information system in developing countries, 24(2):1-19.

Orlikowski, W. J., and Baroudi, J. J. 1991. Studying information Technology in Organizations: Research approaches and assumptions. Information Systems Research, 2(1) p1-28
Oshodi, L. 2010. Housing population and development in Lagos, Nigeria. Housing and urban development. https://oshlookman.wordpress.com/2010/11/24/housingsituation-in-lagos-nigeria. (20 May 2016)

Rajendran, S. and Clarke, B. 2011. Building information modelling, Safety benefits, and opportunities. Professional Safety, October 2011, www.asse.org, pp 46. (10 October 2015)

Rubenstone, J. 2012. Autodesk steers users toward the cloud with expanded subscription-based services. Engineering News Record, April 16, 2012.

Singh, V., Gu, N. and Wang, X. 2010. A theoretical framework of a BIM-based multi-disciplinary collaboration platform. Automation in Construction 20 (2011) 134-144.

Souza, L., Amorim, S., and Magalhães, A. 2009. Impact from the use of BIM in architectural design offices: Real estate market opportunities, Design Management and Technology 1, I. 2.

Vangen, S. and Huxham, C. 2010. Introducing the theory of collaborative advantage, Emerging perspectives on theory and practice of public governance. London: Routledge, 163-184. 